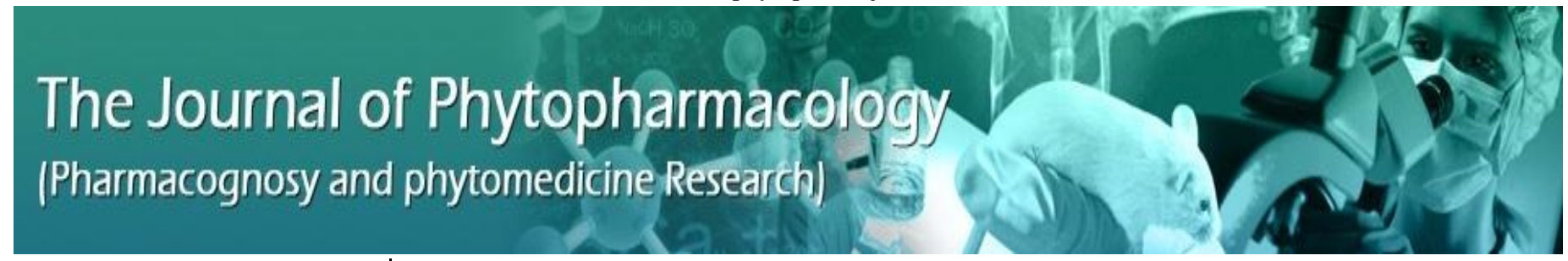

\section{Review Article}

ISSN 2230-480X

JPHYTO 2016; 5(4): 160-166

July- August

() 2016, All rights reserved

Wajid Sarwar

Faculty of Pharmacy, Bahauddin Zakariya University, Multan 60800, Pakistan

\title{
Pharmacological and phytochemical studies on Acacia modesta Wall; A review
}

Wajid Sarwar

\section{ABSTRACT}

The use of plants with therapeutic properties is as ancient as human civilization. Acacia modesta belongs to family Fabaceae and is a deciduous tree which has medium or small size. Traditionally, it has been used to treat leprosy, wounds, dysentery, venereal diseases, cough, body weakness, bacterial infections and backache. Many pharmacological activities have been reported viz. antibacterial, antifungal, anti-hyperglycemic, analgesic, anti-inflammatory, anti-platelet, anti-termite, antioxidant, brine shrimp cytotoxicity, haemagglutination, insecticidal, phytotoxic and spasmolytic. While various flavonoids, terpenoids, alkaloids, tannins, non-protein amino acids, fixed oils and cyclitols have been isolated from this plant. This review is an attempt to provide adequate information on ethno-medicinal uses, general morphology, pharmacological and phytochemical properties of the plant.

Keywords: Acacia modesta, Phulai, pharmacology, Phytochemistry.

\section{INTRODUCTION}

Throughout the ages humans have been using natural products for their basic requirements such as clothing, shelter, food and medicines ${ }^{[1]}$. Especially plants have provided humans with medicines to combat numerous diseases such as malaria, leukemia, diabetes, parasitic infections, respiratory and cardiovascular ailments ${ }^{[2,3]}$.

Acacia modesta belongs to family Fabaceae (subfamily Mimosaceae). It is commonly known as phulai and locally called palosa. It is distributed in Afghanistan, India and Pakistan. In Pakistan it is reported in Punjab, Balochistan and Khyber Pakhtunkhwa ${ }^{[4,5]}$. The wood of A. modesta is durable and hard. It is used for making Persian wheels, cane crushers and agricultural implements. It is also used as fuel ${ }^{[6]}$.

\section{Taxonomy}

Kingdom:

Subkingdom:

Superdivision:

Division:

Class:

Subclass:

Order:

Family:

Subfamily:

Genus:

Species:

Scientific name:

Synonyms:

Various stages of the plant are shown in figure 1.

Plantae - Plants

Rosidae

Fabalace

Fabaceae

Acacia

modesta

Acacia modesta Wall
Correspondence:

Wajid Sarwar

Faculty of Pharmacy, Bahauddin Zakariya University, Multan 60800 Pakistan

Email: drwajidsarwar[at]gmail.com
Tracheobionta - Vascular plants

Spermatophyta - Seed plants

Magnoliophyta - Flowering plants

Magnoliopsida - Dicotyledons

Mimosoideae / Mimosaceae

Sengalia modesta Wall, Mimosa obovata Roxb, Mimosa dumosa Roxb.

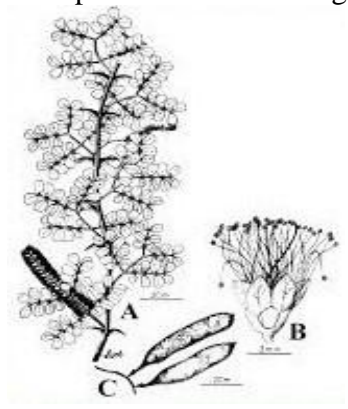

Figure 1: Acacia modesta: A) small branch; B) Flower; C) Fruit 


\section{Ethno-medicinal uses}

It is used to treat leprosy, wounds, dysentery and venereal diseases ${ }^{[7-}$

${ }^{10]}$. Traditionally, ash of $A$. modesta wood was employed for relieving severe body pain. Mixture of gum with wheat flour, almond and butter was given to women after delivery. Zhuble sharbat, solution of gum in water, was taken as health stimulant. Due to antimicrobial properties of A. modesta, its branches were used as miswak (tooth brush). Because of curative properties, gum was used for back pain and sex. Plant use was also seen in treatment of cough ${ }^{[11-15]}$.

\section{Morphology of the plant}

A. modesta is a deciduous tree which has medium or small size. Bark is rough and greenish grey. Prickles are below petioles and in the form of pairs. These prickles are dark brown, compressed, shinning, recurved and 4 to $5 \mathrm{~mm}$ in length while they may be absent in some cases. Pinnae are usually in pairs (2-3) and hardly 1 . Leaflets are also in pairs (3-5), petiolulate, obovate, obtuse, oblique, glaucous and noticeable veins. Inflorescence is pedunculate spike $(3.7-7.5 \mathrm{~cm}$ length) while peduncle is $1.3-2.5 \mathrm{~cm}$. Calyx is glabrous and broadly campanulate, with 1-1.5 mm length. Corolla's length is $2-2.5 \mathrm{~mm}$. Stamens are many. Pods are flat, straight, mucronate, glabrous, stipe and stipitate with variable length ranging from 5-10 mm. Number of seeds varies from 3-5 and flowering season is March to May ${ }^{[4,5]}$.

\section{Pharmacological Properties of $A$. modesta}

Following are the pharmacological activities reports on different parts of Acacia modesta.

\section{Antibacterial activity}

Both gram negative and positive bacteria were used to investigate the methanolic extract of various plants for novel compounds ${ }^{[16]}$. Agar well diffusion was one of the methods used to test the antibacterial effects of $A$. modesta extract ${ }^{[17,18]}$.

Methanol extract and its various fractions showed less activity against gram positive (Streptococcus pneumonia, S. epidermidis and $S$. aureus) and gram negative Enterobacter aerogenes. While moderate activity was seen against gram -ive (P. aeruginosa, S. typhi, E. coli) and gram +ive Bacillus pumilus. The n-hexane and ethyl acetate fraction produced substantial activity against Klebsiella pneumonia. Nevertheless $\mathrm{MIC}_{50}$ values was between $2400-3900 \mu \mathrm{g} / \mathrm{ml}^{[19]}$. A direct relationship was observed between bacterial growth inhibition and conc. of methanol leaves extract ${ }^{[20]}$.

In disc diffusion method, ethanol leaves extract exhibited a significant activity against $P$. aeruginosa, E. coli, K. pneumonia, S. typhi, Proteus mirabilis, S. aureus, Streptococcus pneumonia, B. cereus and B. subtilis. Likewise ethanol: $\mathrm{H}_{2} \mathrm{O}(1: 1)$ extract also showed good activity against above mentioned organisms. When MICs were calculated, it were $4.570-26.500 \mu \mathrm{g} / \mathrm{ml}$ for ethanol extracts and 8.90 $32.50 \mu \mathrm{g} / \mathrm{ml}$ for ethanol: water extracts ${ }^{[21]}$. Hot and cold water extracts showed substantial activity against $S$. aureus, Enterococcus faecalis, $B$. subtilis and $P$. aeruginosa ${ }^{[22]}$.

Root extract of ethanol showed an increase of activity from gram positive, $S$. aureus and $\beta$-Streptococcus to gram negative, E. coli and $K$. pneumonia ${ }^{[23]}$. This extract was bacteriostatic ${ }^{[24]}$. No activity was produced by essential oils of $A$. modesta ${ }^{[25]}$.

\section{Antifungal activity}

Antifungal activity is vital because soil borne fungi may destroy plants and their roots ${ }^{[26,27]}$. The activity was also seen in A. modesta species.
On agar tube dilution assay, methanol extract of leaves showed a growth inhibition of 11.53 and $0.80 \%$ against $A$. niger and $A$. fumigatus respectively ${ }^{[20]}$. When disc diffusion method was employed using C. albicans and Cryptococcus albidus, ethyl alcohol and ethyl alcohol: water (1:1) extracts showed positive response. Ethyl alcohol extract exhibited $\mathrm{MIC}_{50}$ of $0.0055 \mathrm{mg} / \mathrm{ml}$ against $C$. albicans ${ }^{[21]}$. Against $A$. flavus, a very low effect was produced by methyl alcohol aerial parts extract and its fractions ${ }^{[25]}$.

Antifungal activity was enhanced by increasing extract concentration. Root extract of ethanol had more potential against $S$. cerevisiae than hot method extract. The same ethanol extract also showed inhibitory effects against Fusarium sp. and Rhizoctonia solani ${ }^{[23]}$. Action of root extract was fungistatic as it was related to other literature reports ${ }^{[24]}$.

Essential oils had revealed variable inhibitory actions on fungal species ${ }^{[28]}$. A. modesta oils also demonstrated moderate effects (40.0\%) against Microsporum canis. While a less activity against $A$. flavus and $F$. saloni and no activity against $C$. albicans and $C$. glaberata were observed ${ }^{[29]}$.

\section{Anti-hyperglycemic activity}

When rats were given ethanol or ethyl alcohol: water (1:1) extract of the A. modesta leaves, a significant lowering of blood glucose level was observed. The effects were analogous to glibenclamide. $\mathrm{LD}_{50}$ of these extracts were greater than $5000 \mathrm{mg} / \mathrm{kg}$. Ethanol extract, at dose of $100 \mathrm{mg} / \mathrm{kg}$, was $12.34 \%$ extra potent than glibenclamide $(0.20$ $\mathrm{mg} / \mathrm{kg}$ ). While no sign of toxicity was detected in tested rats ${ }^{[21]}$.

\section{Analgesic activity}

Different pain models were used to investigate the A. modesta methanol extract.

Writhing, induced by acetic acid, was considerably diminished by injection (i.p) of the extract to the mice. The result was similar to standard diclofenac sodium. In formalin model, injection of the extract reversed both phases (neurogenic and inflammatory) of licking response in mice. These results were related to centrally acting morphine. During hot plate test, analgesia was produced by methanol extract which was again similar to morphine. Thiopental induced hypnosis test was employed to note the sedative effects of the $A$. modesta extract. In this test, pre-treatment of mice with extract significantly increased the sleep time. This outcome was comparable to standard diazepam ${ }^{[30]}$.

\section{Anti-inflammatory activity}

In carrageenan induced rat paw edema model, methanol extract of the A. modesta exhibited striking anti-phlogistic response. This effect was analogous to diclofenac sodium ${ }^{[30]}$. Literature reports indicated that components involved.in reversal of carrageenan tempted inflammation was also active in cyclooxygenase inhibition ${ }^{[31]}$.

\section{Anti-platelet activity}

Usually COX inhibitors and compounds having anti-inflammatory effects are also active against platelet aggregation ${ }^{[32-34]}$. In case of $A$. modesta $\mathrm{MeOH}$ extract, a dose dependent inhibition was seen against arachidonic acid induced platelet aggregation. $\mathrm{IC}_{50}$ was $0.80 \mathrm{mg} / \mathrm{ml}$ at the dose of $2.50 \mathrm{mg} / \mathrm{ml}^{[30]}$.

\section{Anti-termite activity}

When anti-termite properties of the A. modesta were tested against Heterotermes indicola, a significant activity was showed by methanol extract. The experiment lasted for merely two days. Twenty two termites died on first day while no one stayed alive on day second. 
Similarly the chloroform and aqueous fractions were also active against the termite ${ }^{[35]}$.

\section{Antioxidant activity}

Nitric oxide (NO) is a significant messenger in many physiological and pathological processes ${ }^{[36]}$. But a high level of $\mathrm{NO}$ in tissues is toxic and may contribute to maladies like multiple sclerosis and carcinomas ${ }^{[37]}$. That's why plants samples are screened for nitric oxide free radical sifting. A. modesta $\mathrm{MeOH}$ extract and its ethyl acetate, $n$-hexane, aqueous and chloroform fractions showed modest $\mathrm{NO}$ radical hunting effect at $1.5 \mathrm{mg} / \mathrm{ml}$ concentration. Another model, DPPH assay, also exhibited that plant has antioxidant potential ${ }^{[20,35]}$.

\section{Brine shrimp cytotoxicity}

Cytotoxic effects of plant extracts are tested by using this bioassay because active compounds are usually fatal to Artemia salina ${ }^{[38]}$. In case of methanolic extract of A. modesta, weak toxic activity of $16.6 \%$ was seen at conc. of $1 \mathrm{mg} / \mathrm{ml}$ with $\mathrm{LD}_{50}$ of 4251653.00 . With the aqueous and chloroform fractions, lethal effects of $40 \%$ were observed at $1000 \mu \mathrm{g} / \mathrm{ml}$ conc. While ethyl acetate and $\mathrm{n}$-hexane fractions showed mortality of $26.6 \%$ and $20.0 \%$ respectively at $1 \mathrm{mg} / \mathrm{ml}$ concentration ${ }^{[35]}$.

High toxicity was shown by essential oils of the plant at the conc. of $0.10 \mathrm{mg} / \mathrm{ml}$. When test was performed on thirty shrimps, the number of survivors was zero. This shows that oils can be utilized as cytotoxic product $^{[29]}$.

\section{Haemagglutination activity}

Lectins have been used to demonstrate the functional and structural roles of sugar components present on cell surfaces ${ }^{[39]}$. They have also been employed for characterization and isolation of glycoconjugates ${ }^{[40]}$ and to adhere red blood cells ${ }^{[41]}$.

Haemagglutination activity of A. modesta plant extract was determined by using human's RBCs of different blood groups. Weak or no activity was observed in all blood groups except $\mathrm{O}^{\text {+ive }}$ where ethyl acetate fraction exhibited moderate activity at 1:2 dilution ${ }^{[19]}$

\section{Insecticidal activity}

Synthetic insecticides, because of their toxic side effects, are a great hazard to environment. It intrigued the search for insecticides from natural sources ${ }^{[42]}$. Methanolic extract of $A$. modesta and its fractions were assessed for insecticidal effects against Callosbruchus analis, Rhizopertha dominica and Tribolium castaneum. All test samples exhibited no activity towards $T$. castaneum. Against $R$. dominica, low activity was observed in case of chloroform and $n$-hexane fractions while other samples were inactive. Significant activity of $60 \%$ was seen with n-hexane fraction against $C$. analis $^{[19]}$.

No activity was observed against above mentioned insects when essential oils from the plant were tested. It indicated that these essential oils didn't have insecticidal potential ${ }^{[29]}$.

\section{Phytotoxic activity}

It has been realized that herbicides of natural origin are environment friendly. Consequently, efforts are made to search plant derived herbicides. Lemna assay is used to determine the phytotoxic activity in plants. In case of $A$. modesta, methanolic extract and its different fractions showed little or no activity ${ }^{[19]}$. While essential oils had moderate to low phytotoxic activity ${ }^{[29]}$.

\section{Spasmolytic activity}

When experiment was performed on isolated tissue of rabbit's jejunum by using methanolic extract of $A$. modesta, a dose dependent relaxing effect was observed. With the increase in dose, a decrease was seen in persistent $\mathrm{KCl}$ induced contractions and spontaneous movements. In case of $\mathrm{KCl}$ produced contractions, activity was detected at dose of $0.1 \mathrm{mg} / \mathrm{ml}$ with $\mathrm{EC}_{50}$ of $6.8 \pm 0.53$. This proposed the muscle relaxant effect of the extract ${ }^{[25,43]}$.

\section{Phytochemistry of A. modesta}

Reports on A. modesta aerial parts exposed the presence of flavonoids, alkaloids, terpenoids and tannins [25, 30]. Long chain alcohols [octacosanol (1), nonaeicosanol (2) and hentriacontanol (3)], hydrocarbons [hentriacontane (4) and octacosane (5)], 4-hydroxy benzoic acid (6) and palmitone (7) were also reported ${ }^{[25,44]}$.

\section{Flavonoids}

Flavonoids are polyphenolic compounds. The word "flavonoid".is derived from "flavus" (yellow), a Greek word. These compounds have a diversity in their chemistry and found abundantly in plants. Consequently, they are important part of our food. More than 4000 flavonoids are known. There major groups are flavones, isoflavones, flavanones, flavonols, dihydroflavonols, catechins, chalones and anthocyanidins ${ }^{[45]}$. Whereas Quercetin $(\mathbf{8})$ and kaempherol (9) were extracted from $A$. modesta ${ }^{[46]}$.

\section{Terpenoids}

Terpenoids are vital group of phytochemicals and derived from isoprene units $\left(-\mathrm{C}_{5} \mathrm{H}_{8}\right)$. They may be in the form of mono-, sesqui-, di, tri-, tetra-terpenoids, essential oils and phytosterols ${ }^{[47]}$.

Lupeol (10) was extracted from A. modesta ${ }^{[25]}$. Betulin (11) and $\alpha$ amyrin (12) were present in benzene extract of the stem bark. All of these three compounds are pentacyclic triterpenes. A phytosterol, $\beta$ sitosterol (13), was also obtained from A. modesta ${ }^{[44]}$. When aerial parts of the plant were explored for essential oils, 38 components were obtained $^{[29]}$.

\section{Non-protein amino acids}

These are frequently present in seeds and leaves of Mimosoideae plants ${ }^{[48]}$. Neurolathyrogen/ $\alpha$-amino- $\beta$-oxalylaminopropionic acid (14), was obtained from A. modesta ${ }^{[49]}$.

\section{Fixed oils}

In Acacia species, oils differ a little in their composition. Their triglycerides mainly contain linoleic and oleic acids. Both are unsaturated fatty acids. Seed of A. modesta contained 26 and $27 \%$ linoleic acid (15) and oleic acid (16) respectively ${ }^{[50]}$.

\section{Cyclitols}

Cyclitols are basically cycloalkanes. They contain -OH group on each of ring atoms ${ }^{[51]}$. Pinitol (17) is an important cyclitol having antidiabetic effects ${ }^{[52]}$. It was found in ethanolic extract of A. modesta heartwood ${ }^{[44]}$. 


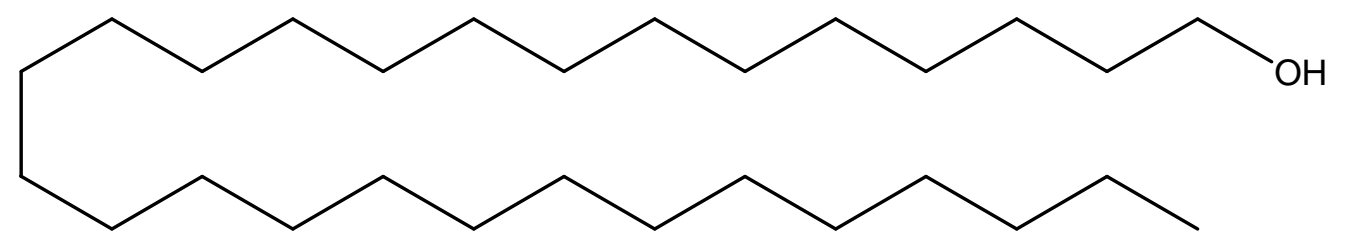

1

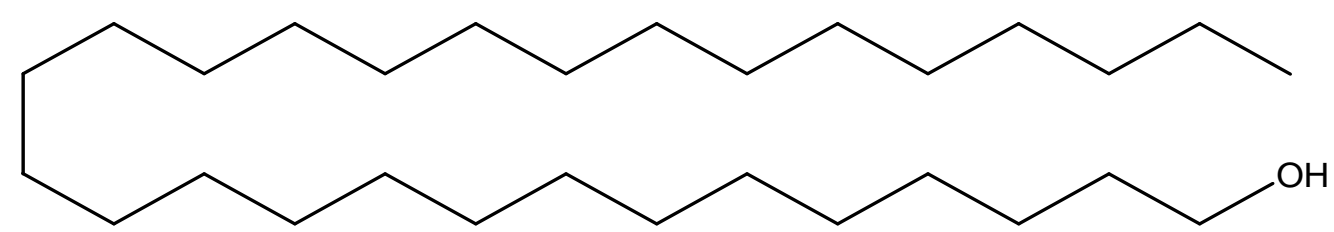

2

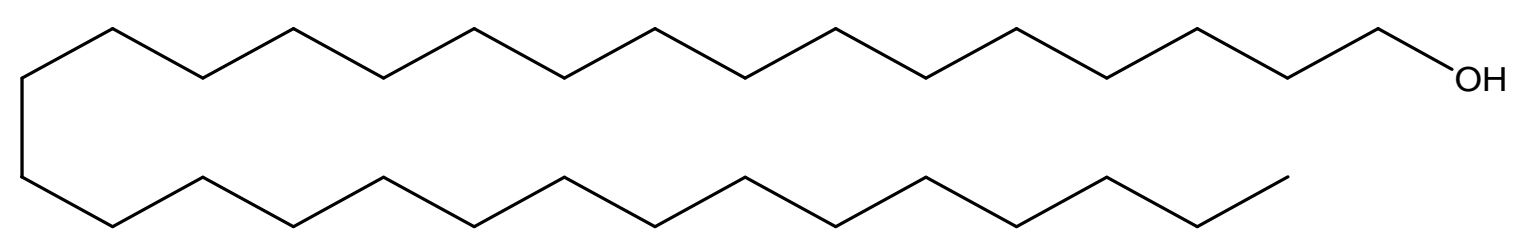

3

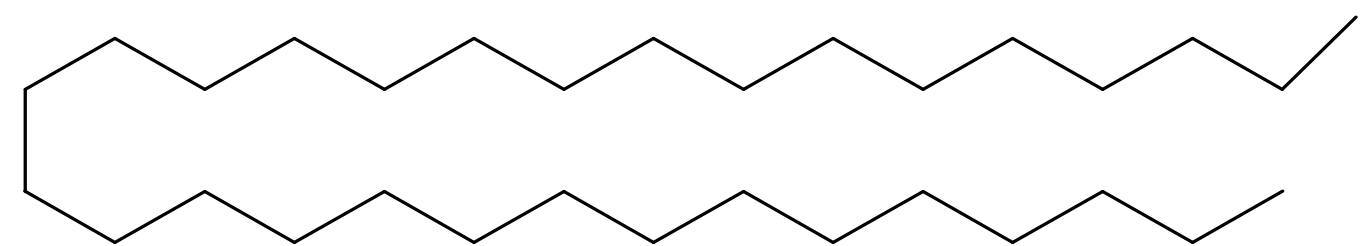

4
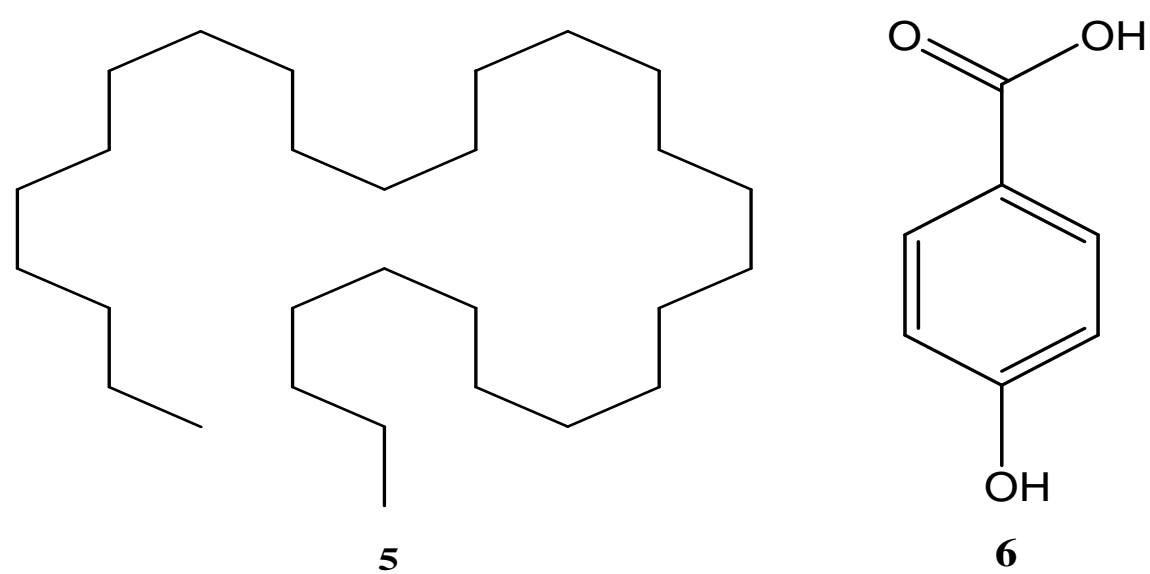

5

6

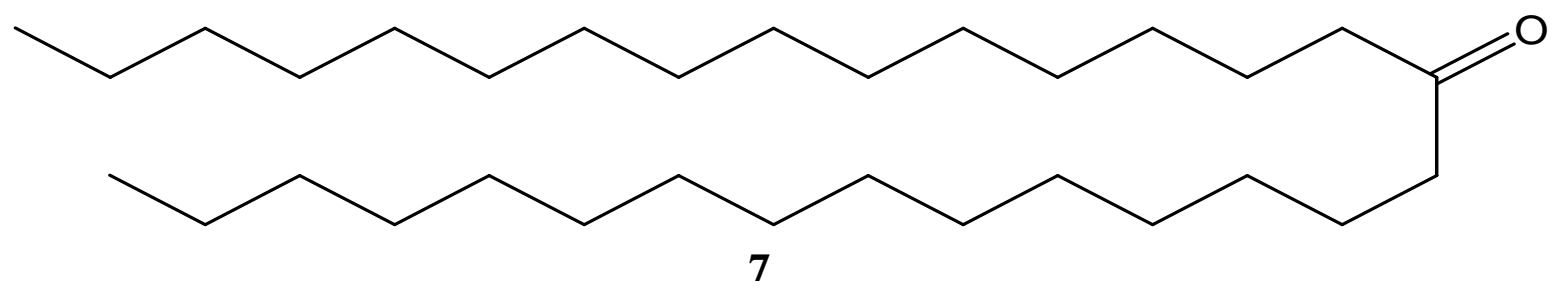


<smiles>O=c1c(O)c(-c2ccc(O)c(O)c2)oc2cc(O)cc(O)c12</smiles>

8<smiles>O=c1c(O)c(-c2ccc(O)cc2)oc2cc(O)cc(O)c12</smiles>

9<smiles>C=C(C)C1CCC2(C)CCC3(C)C(CCC4C5(C)CCC(O)C(C)(C)C5CCC43C)C12</smiles>

10<smiles>C=C(C)C1CCC2(CO)CCC3(C)C(CCC4C5(C)CCC(O)C(C)(C)C5CCC43C)C12</smiles>

11<smiles>CC1CCC2(C)CCC3(C)C(=CCC4C5(C)CCC(O)C(C)(C)C5CCC43C)C2C1C</smiles>

12

13<smiles>NC(CCNC(=O)C(=O)C(=O)O)C(=O)O</smiles>

14<smiles>CCCCC/C=C\C/C=C\CCCCCCCC(=O)O</smiles> 


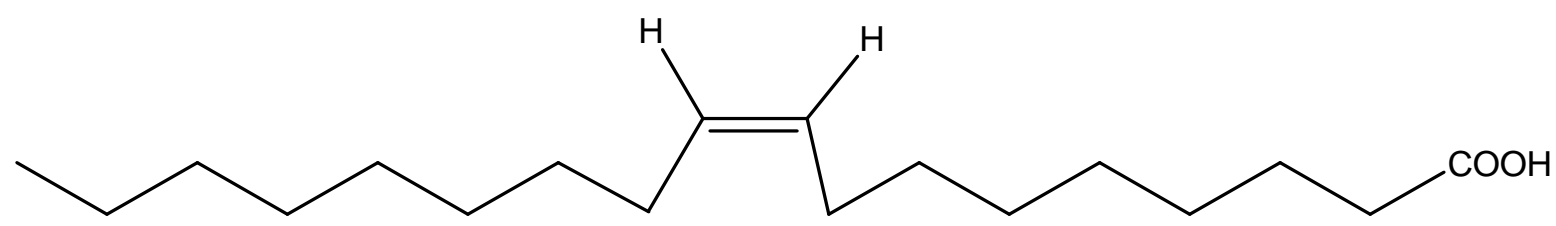

16

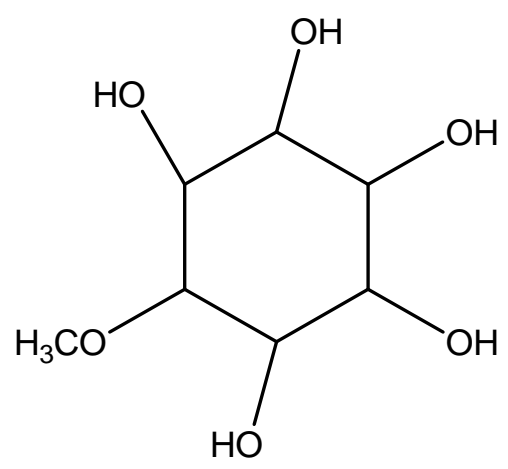

17

\section{CONCLUSION}

This review is the collection of the studies on A. modesta conducted by different scholars and traditional healers which can be further investigated to achieve lead compounds.

\section{Conflict of interest}

None.

\section{REFERENCES}

1. Newman D.J., Cragg G.M., Snader K.M. The influence of natural products upon drug discovery. Natural Product Reports. 2000; 17(3): 215-34.

2. Cragg G.M., Newman D.J. Natural products: a continuing source of novel drug leads. Biochimica et Biophysica Acta (BBA)-General Subjects. 2013; 1830(6): 3670-95.

3. Samuelsson G. Drugs of natural origin: a textbook of pharmacognosy, 596339830, Stockholm: Swedish Pharmaceutical Press. ISBN. 1992: pp. 320.

4. Ali S.I. Mimosaceae. Flora of West Pakistan. 1973.

5. Hook F. Acacia modesta. Flora of British India 2. 1878: pp. 296.

6. Hussain F., Badshah L., Dastagir G. Folk medicinal uses of some plants of South Waziristan, Pakistan. Pakistan Journal of Plant Sciences. 2006 12(1): 27-39.

7. Atta-ur-Rahman S.M., Ahmad V.U. Pakistan Encylcopaedia planta medica vol. I and II. Hamdard Foundation Press, Hamdard Centre, Karachi, Pakistan. 1986.

8. Chopra R.N., Nayar S.L., Chopra I.C. Glossary of Indian medicinal plants. New Delhi. C SIR. 1956: pp. 84.

9. Lewis W.H., Elvin-Lewis M.P. Medical botany: plants affecting human health. John Wiley \& Sons. 2003.

10. Nadkarni K.M. Indian materia medica with ayurvedic, unani-tibbi, siddha, allopathic, homeopathic, naturopathic and home remedies, appendices and indexes. Bombay, Popular Prakashan. 1976: 278-79.

11. Asghar R., Ahmad M., Zafar M., Akram A., Mahmood J., Hassan M. Antibacterial Efficacy of Acacia modesta Wall (Miswak) against Dental Pathogen. Pakistan Journal of Pharmacological Sciences. 2003; 6(24): 2024-25.

12. Hussain F., Badshah L., Dastagir G. Folk medicinal uses of some plants of South Waziristan, Pakistan. Pakistan Journal of Plant Sciences. 2006; 12(1): 27-39.

13. Mahmood T., Khan M.A., Ahmad J., Ahmad M. Ethnomedicinal studies of Kala Chitta hills of district Attock, Pakistan. Asian Journal of Plant Sciences. 2004; 3(3): 335-39.
14. Qureshi R.A., Ahmed M., Ghufran M.A. Indigenous knowledge of some important wild plants as a folk medicines in the area of Chhachh (Distt. Attock) Punjab, Pakistan. Electronic Journal of Environmental, Agriculture and Food Chemistry. 2007; 6(11): 2500-11.

15. Zabihullah Q., Rashid A., Akhtar N. Ethnobotanical survey of Kot Manzary Baba valley, Malakand Agency, Pakistan. Pakistan Journal of Plant Sciences. 2006; 12: 115-21.

16. Bonjar G.S. Evaluation of antibacterial properties of Iranian Medicinal plants against Micrococcus luteus, Serratia marcescens, klebsiella pneumoniae and Bordetella bronchoseptica. Asian Journal of Plant Sciences. 2004; 3(1): 82-86

17. Ahmad B., Ali N., Bashir S., Choudhary M.I., Azam S., Khan I. Parasiticidal, antifungal and antibacterial activities of Onosma griffithii Vatke. African Journal of Biotechnology. 2009; 8(19): 5084-87.

18. Rios J.L., Recio M.C., Villar A. Screening methods for natural products with antimicrobial activity: A review of the literature. Journal of Ethanopharmacology. 1988; 23(2): 127-49.

19. Ahmad B., Khan I., Azam S., Bashir S., Ahmad J., Hussain F. Screening of Acacia modesta for haemagglutination, antibacterial, phytotoxic and insecticidal activities. Journal of Medicinal Plants Research. 2011; 5(14): 3090-96.

20. Napar A.A., Bux H., Zia M.A., Ahmad M.Z., Iqbal A., Roomi S., Muhammad I., Shah S.H. Antimicrobial and antioxidant activities of Mimosaceae plants; Acacia modesta Wall (Phulai), Prosopis cineraria (Linn.) and Prosopis juliflora (Swartz). Journal of Medicinal Plants Research. 2012; 6(15): 2962-70.

21. Jawla S., Kumar Y., Khan M.S.Y. Antimicrobial and antihyperglycemic activities of Acacia modesta leaves. Pharmacologyonline. 2011; 2: 33147.

22. Khalid A., Rehman U., Sethi A., Khilji S., Fatima U., Khan M.I., ...Mahmood, S. Antimicrobial activity analysis of extracts of Acacic modesta, Artimisia absinthium, Nigella sativa and Saussurea lappa against Gram positive and Gram negative microorganisms. African Journal of Biotechnology. 2013; 10(22): 4574-80.

23. Rashid A., Hashmi H. In vitro Susceptibility of some gram positive and gram negative strains of bacteria and fungi to root extracts of Acacia modesta. Pakistan Journal of Pharmacological Sciences. 1999; 2(3): 74649.

24. Tirillini B., Velasquez E.R., Pellegrino R. Chemical composition and antimicrobical activity of essential oil of Piper angustifolium. Planta Medica. 1996; 62(4): 372-73.

25. Khan I. Phytochemical Evalution, Bioassay Screening and Standardization of Zizyphus jujuba and Acacia modesta. $\mathrm{PhD}$. Thesis, University of Peshawar, Khyber Pakhtunkhwa, Pakistan. 2011.

26. Basile A., Vuotto M.L., Violante U., Sorbo S., Martone G., CastaldoCobianchi R. Antibacterial Activity in Actinidia chinensis, Feijoa sellowiana and Aberia caffra. International Journal of Antimicrobial Agents. 1997; 8(3): 199-203. 
27. Roux J., Wingfield M.J. Survey and virulence of fungi occurring on diseased Acacia mearnsii in South Africa. Forest Ecology and Management. 1997; 99(3): 327-36.

28. Alvarez-Castellanos P.P., Bishop C.D., and Pascual-Villalobos M.J. Antifungal activity of the essential oils of flowerheads of garland chrysanthemum (Chrysanthemum coronarium) against agricultural pathogens. Phytochemistry. 2001; 57(1): 99-102.

29. Ahmad B., Khan I., Bashir S., Azam S. Chemical composition and antifungal, phytotoxic, brine shrimp cytotoxicity, insecticidal and antibacterial activities of the essential oils of Acacia modesta. Journal of Medicinal Plants Research. 2012; 6: 4653-59.

30. Bukhari I.A., Khan R.A., Gilani A.H., Ahmed S., Saeed S.A. Analgesic, anti-inflammatory and anti-platelet activities of the methanolic extract of Acacia modesta leaves. Inflammopharmacology. 2010; 18(4): 187-96.

31. Selvam C., Jachak S.M. A cyclooxygenase (COX) inhibitory biflavonoids from the seeds of Semecarpus anacadium. Journal of Ethnopharmacology. 2004; 95(2): 209-12.

32. Jose N., Ajith T.A., Janardhanan K.K. Methanol extract of the oyster mushroom, Pleurotus florida, inhibits inflammation and platelet aggregation. Phytotherapy Research. 2004; 18(1): 43-46.

33. Saeed S.A., Simjee R.U., Shamim G., Gilani A.H. Eugenol: a dual inhibitor of platelet-activating factor and arachidonic acid metabolism. Phytomedicine. 1995; 2(1): 23-28.

34. Siess W., Cuatracasas P., Lepentina E.G. A role for cyclooxygenase products in the formation of phosphatidic acid I stimulated platelets. Journal of Pharmacological Chemistry. 1983; 258(8): 4683-86.

35. Ahmad B., Bashir S., Azam S., Ali N. Screening of Acacia modesta for antifungal, anti-termite, nitric oxide free radical scavenging assay and brine shrimp cytotoxic activities. Journal of Medicinal Plants Research. 2011; 5(15): 3380-86.

36. Hou Y.C., Janczuk A., Wang P.G. Current trends in the development of nitric oxide donors. Current pharmaceutical design. 1999; 5(6): 417-42.

37. Taylor B.S., Kim Y.M., Wang Q.I., Shapiro R.A., Billiar T.R., Geller D.A. Nitric Oxide Down-regulates Hepatocyte-Inducible Nitric Oxide Synthase Gene Expression. Archives of Surgery. 1997; 132(11): 117783.

38. Hussain F., Hameed I., Dastagir G., Khan I., Ahmad B. Cytotoxicity and phytotoxicity of some selected medicinal plants of the family Polygonaceae. African Journal of Biotechnology. 2010; 9(5).

39. Sharon N., Lis H. Lectins: cell-agglutinating and sugar-specific proteins. Science. 1972; 177(4053): 949-59.

40. Kuroki T., Kubota A., Miki Y., Yamamura T., Utsunomiya J. Lectin staining of neoplastic and normal background colorectal mucosa in nonpolyposis and polyposis patients. Diseases of the Colon \& Rectum. 1991; 34(8): 679-84

41. Wei C.H., Koh C.H.O.N.G.K.U.N. Crystalline ricin D, a toxic anti-tumor lectinfrom seeds of Ricinus communis. Journal of Pharmacological Chemistry. 1978; 253(6): 2061-66.

42. Suszkiw J. The formosan termite: a formidable foe. Agricultural Research. 1998; 46(10): 4-9.

43. Ali N., Ahmad B., Bashir S., Shah J., Azam S., Ahmad M. Calcium channel blocking activities of Withania coagulans. African Journal of Pharmacy and Pharmacology. 2009; 3(9): 439-42.

44. Joshi K.C., Tholia M.K., Sharma T. Chemical examination of Acacia modesta. Planta Medica. 1975; 27: 281-83.

45. Cook N.C., Samman S. Flavonoids-chemistry, metabolism, cardioprotective effects, and dietary sources. The Journal of nutritional biochemistry. 1996; 7(2): 66-76.

46. Khan A. Phytochemical and pharmacological studies on Acacia modesta. M.Phil. Thesis, University of Peshawar, Peshawar, Pakistan. 2004.

47. Hanson J.R., Newman A.A. Chemistry of Terpenes and Terpenoids. by AA Newman, Academic Press, London and New York. 1972; 158.

48. Krauss G.J., Reinbothe H. Die freien aminosäuren in samen von Mimosaceae. Phytochemistry. 1973; 12(1): 125-42.

49. Quereshi M.Y., Pilbeam D.J., Evans C.S., Bell E.A. The Neurolathryogen, $\alpha$-Amino- $\beta$-oxalylaminopropionic Acid in Legume Seeds. Phytochemistry. 1977; 16(4): 477-79.

50. Seigler D.S. Phytochemistry of Acacia-sensu lato. Biochemical Systematics and Ecology. 2003; 31(8): 845-73.

51. Wells W.W. (Ed.). Cyclitols and phosphoinositides. Elsevier. 2012: pp. 4.

52. Bates S.H., Jones R.B., Bailey C.J. Insulin-like effect of pinitol. British Journal of Pharmacology. 2000; 130(8): 1944-48.

\section{HOW TO CITE THIS ARTICLE}

Verma S. Medicinal plants with anti-inflammatory activity. J Phytopharmacol 2016;5(4):160-166. 